\title{
Protein/creatinine ratio versus 24-hours urine protein in preeclampsia
}

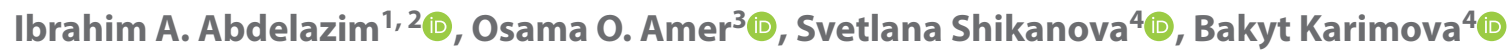 \\ ${ }^{1}$ Department of Obstetrics, and Gynaecology, Ain Shams University, Cairo, Egypt \\ ${ }^{2}$ Ahmadi Hospital, Kuwait Oil Company (KOC), Ahmadi, Kuwait \\ ${ }^{3}$ Ghamra Military Hospital, Cairo, Egypt \\ ${ }^{4}$ West Kazakhstan Marat Ospanov Medical University, Aktobe, Kazakhstan
}

\begin{abstract}
Objectives: Proteinuria is one of the diagnostic criteria of preeclampsia (PE). Measurement of 24-hour urine protein is the gold standard method for detection of proteinuria in PE. The 24-hour urine sampling is time-consuming, and inconvenient. To evaluate the accuracy of protein/creatinine $(P / C)$ ratio in detection of significant proteinuria (>1 g/24-hours urine) in PE. Material and methods: One hundred and ten (110) preeclamptic women were included in this study and admitted for blood pressure monitoring, 24-hour urine collection, fetal well-being assessment and spot urine sample for measuring of $\mathrm{P} / \mathrm{C}$ ratio.

After thorough history and clinical examination, routine antenatal investigations were done for the women included in the study according to the hospital's protocol, and to exclude pre-existing chronic renal disease. Twenty-four-hour urine collection started on the morning following hospital admission. Spot urine samples were obtained shortly before the 24-hour urine collection for measuring of $\mathrm{P} / \mathrm{C}$ ratio. Collected data statistically analyzed to evaluate the accuracy of $\mathrm{P} / \mathrm{C}$ ratio in detection of significant proteinuria in $\mathrm{PE}$.

Results: The P/C ratio of $1.35 \pm 2.54$ had $94.4 \%$ sensitivity, $94.9 \%$ specificity, $97.1 \%$ positive predictive value (PPV), $90.2 \%$ negative predictive value (NPV), and $94.5 \%$ overall accuracy in detection of significant proteinuria (>1 g/24-hour urine) in PE.

Conclusions: The P/C ratio of $1.35 \pm 2.54$ had $94.4 \%$ sensitivity, $94.9 \%$ specificity, $97.1 \%$ PPV, $90.2 \%$ NPV, and $94.5 \%$ overall accuracy in detection of significant proteinuria ( $>1 \mathrm{~g} / 24$-hour urine) in $\mathrm{PE}$. This study suggests the use of $\mathrm{P} / \mathrm{C}$ ratio as an alternative to 24-hour urine protein to detect significant proteinuria in PE.
\end{abstract}

Key words: protein/creatinine ratio; 24-hour urine; protein; preeclampsia (PE)

Ginekologia Polska 2022; 93, 12: 975-979

\section{INTRODUCTION}

Preeclampsia (PE) is a relatively common complication in pregnancy concerning $2-10 \%$ of all pregnancies, and may result in an increase in maternal and fetal mortality [1, 2]

The incidence of PE is greater in developing compared to developed countries $[3,4]$. The incidence of severe PE is $1.3 \%$ in Africa and $0.5 \%$ in Europe including the United Kingdom [5].

Proteinuria is one of the main diagnostic criteria of PE and its severity [6]. The measurement of proteins in 24-hour urine samples is the gold standard method for detection of proteinuria in PE [6]. Twenty-four-hour urine sampling is not always performed correctly, inconvenient, time-consuming, and can delay the diagnosis and treatment [6].

Any methods which may aid earlier detection leading to earlier treatment are extremely valuable in clinical terms. As an alternative to the 24-hour urine collection method, the measurement of protein/creatinine $(\mathrm{P} / \mathrm{C})$ ratio in urine to detect significant proteinuria in PE can be useful, fast tool and easy-to-apply $[7,8]$. 
Therefore, this prospective comparative study designed to evaluate the accuracy of $\mathrm{P} / \mathrm{C}$ ratio in detection of significant proteinuria (>1 g/24-hours urine) in PE.

\section{Objectives}

This study was designed to evaluate the accuracy of $\mathrm{P} / \mathrm{C}$ ratio in detection of significant proteinuria (> $1 \mathrm{~g} / 24$-hour urine) in PE.

\section{MATERIAL AND METHODS}

This prospective comparative study was conducted from December 2018 until August 2020; after approval of the study, and registration as clinical trial (ACTRN12618001910291) [9].

One hundred and ten (110) women between 20-40 years` old, diagnosed as PE after 20 weeks` gestation, were admitted for blood pressure monitoring, 24-hour urine collection, fetal well-being assessment, and spot mid-stream urine sample for measuring of $\mathrm{P} / \mathrm{C}$ ratio after informed consent in accordance with the Declaration of Helsinki.

PE defined according to the ACOG (American College of Obstetricians and Gynecologists) as hypertension, and proteinuria developed after 20 weeks' gestation in a previously normotensive woman [10]

The gestational age calculated according to the last menstrual period and confirmed by an ultrasound scan done $\leq 20$ weeks' gestation [11].

Hypertension defined as blood pressure (BP) $\geq$ $\geq 140 / 90 \mathrm{~mm} \mathrm{Hg}$ on two occasions at least four hours apart after 20 weeks' gestation in a previously normotensive woman or BP $\geq 160 / 110 \mathrm{mmHg}$ within a short interval (even minutes) to facilitate the antihypertensive treatment [10].

Although, the International Society for the Study of Hypertension in Pregnancy (ISSHP) concluded that there is a general agreement to define PE as severe if BP > 160/90 $\mathrm{mmHg}$ and there was scarce agreement on the amount of proteinuria to define the severity of PE [12].

The ACOG defined proteinuria as $\geq 300 \mathrm{mg} / 24$-hours or $\mathrm{P} / \mathrm{C}$ ratio $\geq 0.3$ or dipstick reading +1 (if quantitative methods are not available) [10].

Demirci et al., [6] defined PE as BP $\geq 140 / 90 \mathrm{~mm} \mathrm{Hg}$ after 20 weeks` gestation accompanied by new-onset significant (remarkable) proteinuria ( $\geq 300 \mathrm{mg} / 24$-hours) in a previously normotensive woman [6].

Exclusion criteria include women $>40$ years old, women with chronic hypertension $(\mathrm{CH})$, gestational hypertension $(G H)$, superimposed $P E$, diabetes mellitus, urinary tract infection (UTI), pre-existing chronic renal disease affecting the urine output (UOP) or urine protein and/or creatinine excretion, refused to participate and/or to give consent.

In addition, women with bacteria on urine microscopy or premature rupture of membranes, women with > 24-hours bed rest (to avoid the effect of postural proteinuria on urine-protein excretion), and women practicing heavy or vigorous exercise ( $>1$ hour) on the day of urine collection were also excluded from this study.

GH defined as hypertension of new onset after 20 weeks gestation, in a previously normotensive woman, without proteinuria or manifestations of PE [13].

$\mathrm{CH}$ defined as hypertension that was either diagnosed before pregnancy and/or diagnosed before 20 weeks' gestation and does not resolve by the 12th week postpartum [13].

Superimposed PE defined as $\mathrm{CH}$ diagnosed before pregnancy and/or before 20 weeks' gestation that complicated with proteinuria, and severe PE [13].

After thorough history, and clinical examination, routine antenatal investigations were for the women taking part in the study according to the hospital's protocol, and to exclude pre-existing chronic renal disease.

Participants were admitted for 24-hours for blood pressure monitoring, fetal well-being assesment (Cardiotocography (CTG), detailed fetal ultrasound, and umbilical artery Doppler), as well as for 24-hour urine collection, which started on the morning following hospital admission. Spot mid-stream urine sample obtained (first morning urine sample) shortly before the 24-hour urine collection for measuring $\mathrm{P} / \mathrm{C}$ ratio.

Urinary protein measured by the Biuret colorimetric method (Cobas Integra Analyzer, Basel, Switzerland) [14]. Urine creatinine measured by the modified Jaffe test (Hitachi 7170 Autoanalyzer, Tokyo, Japan) [6]. Collected data statistically analyzed to evaluate the accuracy of $\mathrm{P} / \mathrm{C}$ ratio in detection of significant proteinuria (> $1 \mathrm{~g} / 24$-hours urine) in PE.

\section{Sample size justification}

The required sample size calculated from the previous studies [14, 15], and using G Power software version 3.1.9 for sample size calculation, setting a -error probability at 0.05 , power (1- $\beta$ error probability) at $0.95 \%$, and effective sample size (w) at 0.5 . An effective sample $\geq 220$ women was needed to produce a statistically acceptable figure.

\section{Statistical analysis}

Collected data were statistically analyzed using Statistical Package for Social Sciences (SPSS): computer software version 20 (Chicago, IL, USA). Numerical variables were presented as mean and standard deviation ( \pm SD), while categorical variables were presented as number (n) and percentage (\%). Sensitivity: proportional detection of individuals with the disease of interest in the population. Specificity: proportional detection of individuals without the disease of interest in the population. Positive predictive value (PPV): proportion of all individuals with positive tests, 


\begin{tabular}{|c|c|}
\hline Variables & $\begin{array}{l}\text { Total number of the studied } \\
\text { women ( } 110 \text { women) }\end{array}$ \\
\hline Maternal age (years) & $27.5 \pm 4.2$ \\
\hline $\begin{array}{l}\text { Parity } \\
\text { Nulliparous } \\
\text { Multiparous }\end{array}$ & $\begin{array}{l}67 / 110(60.9 \%) \\
43 / 110(39.1 \%)\end{array}$ \\
\hline History of PE & $12 / 110(10.9 \%)$ \\
\hline $\begin{array}{l}\text { Gestational age (weeks') } \\
<34 \text { weeks' gestation } \\
>34 \text { weeks' gestation }\end{array}$ & $\begin{array}{l}59 / 110(53.6 \%) \\
51 / 110(46.4 \%)\end{array}$ \\
\hline Blood urea (mg/dL) & $12.7 \pm 3.9$ \\
\hline Serum creatinine (mg/dL) & $0.83 \pm 1.6$ \\
\hline Total serum proteins ( $\mathrm{g} / \mathrm{dL})$ & $6.7 \pm 1.3$ \\
\hline Serum albumin (g/dL) & $4.1 \pm 1.6$ \\
\hline Urinary protein (mg/24-hrs) & $1393.5 \pm 670$ \\
\hline Spot urine protein $(\mathrm{mg} / \mathrm{dL})$ & $157 \pm 212$ \\
\hline Spot urine creatinine (mg/dL) & $116 \pm 83.5$ \\
\hline Protein/creatinine $(\mathrm{P} / \mathrm{C})$ ratio & $1.35 \pm 2.54$ \\
\hline
\end{tabular}

$\mathrm{P} / \mathrm{C}$ ratio — Protein/creatinine ratio; $\mathrm{PE}$ — Preeclampsia

who have the disease. Negative predictive value (NPV): proportion of all individuals with negative tests, who are non-diseased.

\section{RESULTS}

One hundred and ten (110) preeclamptic women were admitted for blood pressure monitoring, 24-hour urine collection, fetal well-being assesment, and spot mid-stream urine sample for measuring of $\mathrm{P} / \mathrm{C}$ ratio. The mean age of the studied woman was $27.5 \pm 4.2$ years, $60.9 \%$ (67/110) of participants were nulliparous, while $39.1 \%(43 / 110)$ were multiparous, and $10.9 \%$ of participants had previous history of PE.

Regarding the gestational age at diagnosis of $\mathrm{PE}$, PE diagnosed at $<34$ weeks ' in 53.6\% (59/110) of participants, while it was diagnosed at $>34$ weeks' in $46.4 \%$ $(51 / 110)$ of them.

The mean blood urea of the participants was $12.7 \pm 3.9 \mathrm{mg} / \mathrm{dL}$, serum creatinine was $0.83 \pm 1.6 \mathrm{mg} / \mathrm{dL}$, total serum proteins was $6.7 \pm 1.3 \mathrm{~g} / \mathrm{dL}$, and serum albumin was $4.1 \pm 1.6 \mathrm{~g} / \mathrm{dL}$.

The mean 24-hour protein of the participants was $1393.5 \pm 670 \mathrm{mg} / 24$-hour, spot urine protein was $157 \pm 212 \mathrm{mg} / \mathrm{dL}$, spot urine creatinine was $116 \pm 83.5 \mathrm{mg} / \mathrm{dL}$, and $\mathrm{P} / \mathrm{C}$ ratio was $1.35 \pm 2.54$. Table 1 .

The studied women categorized into two groups according to 24-hour urine proteins; proteinuria > $1 \mathrm{~g} / 24$-hour urine, and proteinuria $<1 \mathrm{~g} / 24$-hour urine to evaluate
Table 2. Accuracy of the $P / C$ ratio in detection of significant proteinuria (> $1 \mathrm{~g} / 24$-hours urine) in PE

\begin{tabular}{|c|c|}
\hline $\begin{array}{l}\text { Variables } \\
\text { Number of the studied women (110 } \\
\text { women) }\end{array}$ & Number (\%) \\
\hline $\begin{array}{l}\text { Proteinuria }>1 \mathrm{~g} / 24 \text {-hours urine } \\
\text { ( } 71 \text { women) } \\
\text { True positive (TP) } \\
\text { False negative (FN) }\end{array}$ & $\begin{array}{l}67 / 71(94.4 \%) \\
4 / 71(5.6 \%)\end{array}$ \\
\hline $\begin{array}{l}\text { Proteinuria }<1 \mathrm{~g} / 24 \text {-hours urine } \\
\text { ( } 39 \text { women) } \\
\text { True negative (TN) } \\
\text { False positive (FP) }\end{array}$ & $\begin{array}{l}37 / 39(94.9 \%) \\
2 / 39(5.1 \%)\end{array}$ \\
\hline Sensitivity & $\begin{array}{l}67 \div(67+4) X \\
100=(94.4 \%)\end{array}$ \\
\hline Specificity & $\begin{array}{l}37 \div(37+2) X \\
100=(94.9 \%)\end{array}$ \\
\hline Positive predictive value (PPV) & $\begin{array}{l}67 \div(67+2) X \\
100=(97.1 \%)\end{array}$ \\
\hline Negative predictive value (NPV) & $\begin{array}{l}37 \div(37+4) X \\
100=(90.2 \%)\end{array}$ \\
\hline Accuracy & $\begin{array}{l}67+37 \div(67+4+37+2) X \\
100=(94.5 \%)\end{array}$ \\
\hline
\end{tabular}

$\mathrm{P} / \mathrm{C}$ ratio — Protein/creatinine ratio; $\mathrm{PE}$ — Preeclampsia

the accuracy of $\mathrm{P} / \mathrm{C}$ ratio in detection of significant proteinuria (> $1 \mathrm{~g} / 24$-hour urine) in $\mathrm{PE}$.

In proteinuria $>1 \mathrm{~g} / 24$-hour urine group; the $\mathrm{P} / \mathrm{C}$ ratio was true positive (TP) in $94.4 \%$ (67/71), and it was false negative (FN) in 5.6\% (4/71), while in proteinuria > $1 \mathrm{~g} / 24$-hour urine group; the $\mathrm{P} / \mathrm{C}$ ratio was true negative (TN) in 37/39 (94.9\%), and it was false positive (FP) in 3/39 (5.1\%).

The $\mathrm{P} / \mathrm{C}$ ratio of $1.35 \pm 2.54$ had $94.4 \%$ sensitivity, $94.9 \%$ specificity, 97.1\% PPV, 90.2\% NPV, and $94.5 \%$ overall accuracy in detection of significant proteinuria (>1 g/24-hours urine) in PE (Tab. 2).

\section{DISCUSSION}

One hundred and ten (110) preeclamptic women were admitted for blood pressure monitoring, 24-hour urine collection, and spot mid-stream urine sample for measuring of $\mathrm{P} / \mathrm{C}$ ratio.

The women participating in the study categorized into two groups according to 24-hour urine proteins; proteinuria $>1 \mathrm{~g} / 24$-hour urine, and proteinuria $<1 \mathrm{~g} / 24$-hour urine to evaluate the accuracy of $\mathrm{P} / \mathrm{C}$ ratio in detection of significant proteinuria (> $1 \mathrm{~g} / 24$-hour urine) in PE.

The mean age of the studied woman was $27.5 \pm 4.2$ years, $60.9 \%(67 / 110)$ of participants were nulliparous, while $39.1 \%$ $(43 / 110)$ were multiparous, and $10.9 \%$ of participants had previous history of PE.

Regarding the gestational age at diagnosis of $\mathrm{PE}$, PE diagnosed at $<34$ weeks` in 53.6\% (59/110) of par- 
ticipants, while it was diagnosed at > 34 weeks` in $46.4 \%$ $(51 / 110)$ of them.

Demirci et al., studied 211 preeclamptic women and found the mean maternal age of their studied women was $28.2 \pm 5.5$ years. Fifty-six percent of them were nulliparous and $8.5 \%$ of them had previous history of PE. Regarding the gestational age at the diagnosis of PE, Dermirci et al. [6], found that $52.6 \%$ of their studied preeclamptic women were $<34$ weeks', while $47.4 \%$ of them were $\geq 34$ weeks'.

Shahbazian et al., studied 81 preeclamptic women, and found the mean maternal age was $26.5 \pm 3.6$ years, and the mean gestational age at diagnosis of PE was $34.4 \pm 4.7$ weeks` [14].

Abdelazim et al., concluded that women with PE/superimposed $\mathrm{PE}$ were significantly younger with low parity compared to $\mathrm{CH}$ group, and the gestational age at diagnosis and delivery of PE/superimposed PE was $35.2 \pm 1.3$ weeks compared to $37.6 \pm 0.9$ weeks` for $\mathrm{CH}$ group [13].

Women with UTI, pre-existing chronic renal disease affecting the UOP or urine protein and/or creatinine excretion were excluded from this study. This explains why all participants had normal blood urea, and serum creatinine $(12.7 \pm 3.9$ and $0.83 \pm 1.6 \mathrm{mg} / \mathrm{dL}$; respectively $)$, normal total serum proteins, and serum albumin $(6.7 \pm 1.3$ and $4.1 \pm 1.6 \mathrm{~g} / \mathrm{dL}$; respectively).

Similarly, the median serum creatinine was $0.52 \mathrm{mg} / \mathrm{dL}$ in Shahbazian et al., [14] study, and the mean serum creatinine was $0.64 \pm 0.4 \mathrm{mg} / \mathrm{dL}$ in Demirci et al. [6], study.

The mean 24-hour protein of the studied women was $1393.5 \pm 670 \mathrm{mg} / 24$-hour urine $(1.393 \pm 0.67 \mathrm{~g} / 24$-hours urine), spot urine protein was $157 \pm 212 \mathrm{mg} / \mathrm{dL}$, spot urine creatinine was $116 \pm 83.5 \mathrm{mg} / \mathrm{dL}$, and $\mathrm{P} / \mathrm{C}$ ratio was $1.35 \pm 2.54$. The mean $\mathrm{P} / \mathrm{C}$ ratio of $1.35 \pm 2.54$ had 94.4\% sensitivity, 94.9\% specificity, 97.1\% PPV, 90.2\% NPV, and $94.5 \%$ overall accuracy in detection of significant proteinuria (> $1 \mathrm{~g} / 24$-hour urine) in preeclamptic women.

Demirci et al., found that the $\mathrm{P} / \mathrm{C}$ ratio of $0.45 \%$ corresponds to 24-hour proteinuria of $300 \mathrm{mg} / 24$ hours with $74.4 \%$ sensitivity, $94.2 \%$ specificity, $98.1 \%$ PPV, and $47.6 \% \mathrm{NPV}$, while the $\mathrm{P} / \mathrm{C}$ ratio of 0.9 corresponds to 24-hour proteinuria of $1000 \mathrm{mg} / 24$ hours with $91 \%$ sensitivity, 95.4\% specificity, 95.2\% PPV, and 91.2\% NPV, and $\mathrm{P} / \mathrm{C}$ ratio of 1.16 corresponds to 24 -hour proteinuria of $2000 \mathrm{mg} / 24$ hours with $95.8 \%$ sensitivity, $85.1 \%$ specificity, 78.4\% PPV, and 97.3\% NPV [6].

Shahbazian et al., found that the mean 24-hours protein of preeclamptic women was $1790 \pm 0.80 \mathrm{mg} / 24$-hours, and mean $\mathrm{P} / \mathrm{C}$ ratio was $1.84 \pm 0.91$ [14].

Shahbazian et al., concluded that the $\mathrm{P} / \mathrm{C}$ ratio of 0.20 corresponds to $300 \mathrm{mg} / 24$ hour urine protein with high accuracy (91.2\% sensitivity, $87.8 \%$ specificity, $94.4 \%$ PPV and $96.8 \%$ NPV), and spot $P / C$ ratio $<0.19$ could exclude PE with $100 \%$ sensitivity [14].

In addition, Wheeler et al., found that the $\mathrm{P} / \mathrm{C}$ ratio of $0.21,0.46,0.82$, and 3.0 corresponds to $300,1000,2000$, and $5000 \mathrm{mg} / 24$ hour-urine protein, respectively [15].

Although a recent meta-analysis concluded that the optimum threshold for $\mathrm{P} / \mathrm{C}$ ratio to detect significant proteinuria is between 0.30 and 0.35 [16], Demirci et al., found that a spot $\mathrm{P} / \mathrm{C}$ ratio $>0.9$ strongly predicts significant proteinuria $>1 \mathrm{~g} / 24$-hour urine with $91 \%$ sensitivity, $95.4 \%$ specificity, 95.2\% PPV, and 91.2\% NPV [6]. In addition, this study found the $\mathrm{P} / \mathrm{C}$ ratio of $1.35 \pm 2.54$ had $94.4 \%$ sensitivity, 94.9\% specificity, 97.1\% PPV, 90.2\% NPV, and 94.5\% overall accuracy in detection of significant proteinuria [ $>1 \mathrm{~g}$ (1.393 g/24-hour urine)] in PE.

The National Kidney Foundation Guidelines suggested the spot urine samples to detect and monitor proteinuria in adults [7], and the 24-hour urine sampling is not always performed correctly, inconvenient, and time-consuming [6].

Morales et al., also reported the potential error in detecting proteinuria in spot urine sample does not exceed the error in collecting the 24-hour urine sample [17].

Moreover, the 24-hour protein can be calculated from the $P / C$ ratio in spot urine sample using the following equation: 24 -hour urine protein in grams $=0.81 \mathrm{XP} / \mathrm{C}$ ratio +0.3 .

This study found that the $\mathrm{P} / \mathrm{C}$ ratio of $1.35 \pm 2.54 \mathrm{had}$ 94.4\% sensitivity, 94.9\% specificity, 97.1\% PPV, 90.2\% NPV, and $94.5 \%$ overall accuracy in detection of significant proteinuria (> $1 \mathrm{~g} / 24$-hour urine) in PE. The high predictive value of the $\mathrm{P} / \mathrm{C}$ ratio in detection of significant proteinuria in this study can be explained by the strict exclusion criteria of the study.

This study suggests the use of $\mathrm{P} / \mathrm{C}$ ratio as an alternative to 24-hour urine protein to detect significant proteinuria in PE.

The absence of regular pregnancy controls, and women refused to participate and/or give consent were the limitations faced during this study.

This study was the first registered study designed to evaluate the accuracy of $\mathrm{P} / \mathrm{C}$ ratio in detection of significant proteinuria (> $1 \mathrm{~g} / 24$-hour urine) in PE.

\section{CONCLUSIONS}

The $\mathrm{P} / \mathrm{C}$ ratio of $1.35 \pm 2.54$ had $94.4 \%$ sensitivity, $94.9 \%$ specificity, 97.1\% PPV, 90.2\% NPV, and $94.5 \%$ overall accuracy in detection of significant proteinuria (> $1 \mathrm{~g} / 24$-hour urine) in PE. This study suggests the use of $\mathrm{P} / \mathrm{C}$ ratio as an alternative to 24-hour urine protein to detect significant proteinuria in PE. 


\section{Acknowledgments}

Authors are also grateful to women agreed and gave consent to participate in this study.

\section{Conflict of interest}

All authors declare no conflict of interest.

\section{REFERENCES}

1. Osungbade $\mathrm{KO}$, Ige OK. Public health perspectives of preeclampsia in developing countries: implication for health system strengthening. J Pregnancy. 2011; 2011: 481095, doi: 10.1155/2011/481095, indexed in Pubmed: 21547090.

2. Wallis AB, Saftlas AF, Hsia J, et al. Secular trends in the rates of preeclampsia, eclampsia, and gestational hypertension, United States, 1987-2004. Am J Hypertens. 2008; 21(5): 521-526, doi: 10.1038/ajh.2008.20, indexed in Pubmed: 18437143.

3. Ananth CV, Basso O. Impact of pregnancy-induced hypertension on stillbirth and neonatal mortality. Epidemiology. 2010; 21(1): 118-123, doi: 10.1097/EDE.0b013e3181c297af, indexed in Pubmed: 20010214.

4. Famurewa AC, Ugwuja El, Ikaraoha Cl. Comparison of serum calcium and magnesium between preeclamptic and normotensive pregnant Nigerian women in Abakaliki, Nigeria. Annals of Medical and Health Sciences Research. 2016; 6(1): 33, doi: 10.4103/2141-9248.180269.

5. Ngwenya S. Severe preeclampsia and eclampsia: incidence, complications, and perinatal outcomes at a low-resource setting, Mpilo Central Hospital, Bulawayo, Zimbabwe. Int J Womens Health. 2017; 9: 353-357, doi: 10.2147/IJWH.S131934, indexed in Pubmed: 28553148.

6. Demirci O, Kumru P, Arınkan A, et al. Spot protein/creatinine ratio in preeclampsia as an alternative for 24 -hour urine protein. Balkan Med J. 2015; 32(1): 51-55, doi: 10.5152/balkanmedj.2015.15447, indexed in Pubmed: 25759772.

7. Keane W, Eknoyan G. Proteinuria, albuminuria, risk, assessment, detection, elimination (PARADE): A position paper of the National Kidney Foundation. American Journal of Kidney Diseases. 1999; 33(5): 1004-1010, doi: 10.1016/s0272-6386(99)70442-7.
8. Price CP, Newall RG, Boyd JC. Use of protein:creatinine ratio measurements on random urine samples for prediction of significant proteinuria: a systematic review. Clin Chem. 2005; 51(9): 1577-1586, doi: 10.1373/clinchem.2005.049742, indexed in Pubmed: 16020501.

9. Protein/Creatinine ratio versus 24 -Hour urine protein in preeclampsia. http://www.ANZCTR.org.au/ACTRN12618001910291.aspx (30.12.2020).

10. Hypertension in pregnancy. Report of the American College of Obstetricians and Gynecologists' task force on hypertension in pregnancy. Obstet Gynecol. 2013; 122(5): 1122-1131, doi: 10.1097/01. AOG.0000437382.03963.88, indexed in Pubmed: 24150027.

11. Farghali M, Abdelazim I, Abdelrazek K. Delayed second twin delivery: benefits and risks. J Matern Fetal Neonatal Med. 2019; 32(10): 1626-1632, doi: 10.1080/14767058.2017.1413547, indexed in Pubmed: 29198155.

12. Tranquilli AL, Brown MA, Zeeman GG, et al. The definition of severe and early-onset preeclampsia. Statements from the International Society for the Study of Hypertension in Pregnancy (ISSHP). Pregnancy Hypertens. 2013; 3(1): 44-47, doi: 10.1016/j.preghy.2012.11.001, indexed in Pubmed: 26105740 .

13. Abdelazim IA, Bekmukhambetov $Y$, Aringazina $R$, et al. The outcome of hypertensive disorders with pregnancy. J Family Med Prim Care. 2020; 9(3): 1678-1683, doi: 10.4103/jfmpc.jfmpc_1054_19, indexed in Pubmed: 32509671.

14. Shahbazian N, Hosseini-Asl F. A comparison of spot urine protein-creatinine ratio with 24-hour urine protein excretion in women with preeclampsia. Iran J Kidney Dis. 2008; 2:127-31. Indexed in Pubmed:19377225.

15. Wheeler TL, Blackhurst DW, Dellinger EH, et al. Usage of spot urine protein to creatinine ratios in the evaluation of preeclampsia. Am J Obstet Gynecol. 2007; 196(5): 465.e1-465.e4, doi: 10.1016/j.ajog.2006.10.892, indexed in Pubmed: 17466704.

16. Morris RK, Riley RD, Doug M, et al. Diagnostic accuracy of spot urinary protein and albumin to creatinine ratios for detection of significant proteinuria or adverse pregnancy outcome in patients with suspected pre-eclampsia: systematic review and meta-analysis. BMJ. 2012; 345: e4342, doi: 10.1136/bmj.e4342, indexed in Pubmed: 22777026.

17. Morales JV, Weber R, Wagner MB, et al. Is morning urinary protein/creatinine ratio a reliable estimator of 24-hour proteinuria in patients with glomerulonephritis and different levels of renal function? J Nephrol. 2004;17(5):666-72. Indexed in Pubmed: 15593033 